\title{
PTEROCAESIO TESSELLATA (ACTINOPTERYGII: PERCIFORMES: CAESIONIDAE) FROM TAIWAN: EXTENDED DISTRIBUTION RANGE
}

\author{
Keita $\mathrm{KOEDA}^{1^{*}}$ and Hsuan-Ching $\mathrm{HO}^{1,2}$ \\ ${ }^{1}$ National Museum of Marine Biology \& Aquarium, Checheng, Pingtung, Taiwan \\ ${ }^{2}$ Institute of Marine Biology, National Dong Hwa University, Pingtung, Taiwan
}

Koeda K., Ho H.-C. 2019. Pterocaesio tessellata (Actinopterygii: Perciformes: Caesionidae) from Taiwan: extended distribution range. Acta Ichthyol. Piscat. 49 (1): 79-84.

\begin{abstract}
Six species of the genus Pterocaesio (Caesionidae) have previously been recorded from Taiwanese waters. Although Pterocaesio tessellata Carpenter, 1987 is known from the eastern Indian to the western Pacific oceans north to the Philippines, it has not previously been reported from Taiwan. The main objective of this paper is to document the presence of this species in the waters of Taiwan. A single specimen (101.6 mm standard length) of Pterocaesio tessellata was collected from south-western Taiwan in 2018. The morphology and fresh coloration of the collected specimen are herein described. The majority of the morphological characters closely align with the original descriptions of holotype and paratypes of Pterocaesio tessellata: dorsal fin with 10 spines and 15 soft rays; anal fin with 12 soft rays; pectoral fin with 20 rays; lateral-line scales 73; circumpeduncular scales 13 +15 ; a single yellow longitudinal stripe on body lateral, about a single scale wide, from upper margin of eye to caudal peduncle, covering lateral line for most of its length. Therefore, the specimen from south-western Taiwan is identified as Pterocaesio tessellata. The presently reported specimen represents the first record for Taiwan, as well as the northernmost record of this species up to now. An identification key to the species of genus Pterocaesio in Taiwan is shown.
\end{abstract}

Keywords: taxonomy, distribution, coral reef, Pterocaesio digramma, Pterocaesio chrysozona

\section{INTRODUCTION}

The genus Pterocaesio Bleeker, 1876, belong to the family Caesionidae and currently consist of 12 valid species (Fricke et al. 2018). Six of these species have previously been recorded from Taiwanese waters (Shen and $\mathrm{Wu} 2011$, Koeda and Ho 2018), including Pterocaesio chrysozona (Cuvier, 1830), Pterocaesio digramma (Bleeker, 1864), Pterocaesio marri Schultz, 1953, Pterocaesio pisang (Bleeker, 1853), Pterocaesio randalli Carpenter, 1987, and Pterocaesio tile (Cuvier, 1830).

A single specimen of Pterocaesio tessellata Carpenter, 1987 was recently collected off Kaohsiung south-western Taiwan. This species has been known from the eastern Indian and western Pacific oceans north to the Philippines (Carpenter 1987). The presently reported specimen is herein described as the first record of $P$. tessellata from Taiwan and the northernmost record of this species. In addition, an identification key to the seven species of genus Pterocaesio present in Taiwanese waters is included along with photographs of congeners of the present species.

\section{MATERIALS AND METHODS}

Counts and measurements follow Carpenter (1987). Measurements were made to the nearest $0.1 \mathrm{~mm}$ with needle- point callipers under a dissecting microscope. Standard and head lengths are abbreviated as SL and HL, respectively. The morphological description is based on the specimen collected from Taiwan. The specimens of genus Pterocaesio examined in this study are deposited at the Kagoshima University Museum (KAUM) and the National Museum of Marine Biology \& Aquarium (NMMB).

Specimen examined. KAUM-I. 115115, $101.6 \mathrm{~mm}$ SL, off Kaohsiung, landed at Ke-zi-liao Fishing Landing Port, 10 May 2018.

\section{RESULTS}

\author{
Family Caesionidae \\ Pterocaesio Bleeker, 1876 \\ Pterocaesio tessellata Carpenter, 1987 \\ 単带鱗鯺烏尾鮗 (New Taiwanese name) \\ Fig. 1; Table 1
}

Pterocaesio tessellata Carpenter, 1987; Carpenter 1987: 47 (type locality: Cebu, Philippines). Myers 1999: 148, pl. 66, fig. A; Carpenter 2000: 618; Carpenter 2001: 2939; Allen and Adrim 2003: 39; Peristiwady et al. 2003: 92; Adrim et al. 2004: 121; Iwatsuki 2009: 147, unnumbered fig.; Allen and Erdmann 2012: 466, unnumbered fig.; Fricke et al. 2014: 90; Tatsukawa 2017: 139, unnumbered fig. 
Description of Taiwanese specimen. (Counts and measurements of the presently reported specimen are given in Table 1.) Body moderately elongate and fusiform; depth of caudal peduncle less than $1 / 3$ of body depth. Head pointed; dorsal profile of head equally sloping. Interorbital space convex. Anterior nostril with low membranous rim, closer to orbit than snout; posterior nostril without rim or flap. Margin of opercle with dorsoposterior flap. Lateral line nearly straight from upper end of opercle to middle of caudal-fin base.

Mouth oblique, forming angle of about $40^{\circ}$ to horizontal, lower jaw projecting slightly; maxilla extending posterior to vertical at anterior edge of orbit. Jaws with minute conical teeth; premaxilla with single row of teeth restricted to anteriormost portion; lower jaw with single row of teeth laterally, becoming patch anteriorly; teeth in lateral row distinctly less numerous just posterior to apex of jaw; vomer and palatines edentate. Origin of dorsal fin posterior to vertical above pelvic-fin origin; $1 \mathrm{st}$ dorsal-fin spine short, its base close to base of 2nd spine; dorsal-fin spines and soft rays anterior to 5th dorsal-fin spine gradually shorter. 1st of anal fin below base of 1 st soft ray of dorsal fin; 1 st spine of anal fin shorter than 2 nd and 3rd spines; first soft ray of anal fin longest. Dorsal and anal fins scaled, dorsal with $4 / 5-1 / 2$ of its greatest spinous height covered with scales. Pectoral fins pointed, 5th ray longest, reaching vertical drawn through base of 8th spine in dorsal fin. Origin of pelvic fin slightly posterior to lower base of pectoral fin. Caudal fin deeply forked.

Coloration - When fresh, body and head pink, dark red dorsally; a single yellow longitudinal stripe on body lateral, about a single scale wide, from upper margin of eye to caudal peduncle, covering lateral line for most of its length; snout faintly yellowish. Dorsal-fin faint yellowish with pink outer margin; anal fin and pelvic fin pinkish white; pectoral fin pinkish translucent, axil black; caudal fin red with dark red to brown blotch on tip of upper and lower lobes. When preserved, body and head pale with dark pigments on centre of scales of body lateral; longitudinal stripe disappeared; dark blotch on tip of caudal-fin lobes.

Distribution. Pterocaesio tessellata is currently known from the eastern Indian to the western Pacific oceans, westward to Sri Lanka, eastward to Vanuatu, and north to the Philippines (Carpenter 1987, 2001, Allen and Erdmann 2012, Tatsukawa 2017), and now from southwestern Taiwan (presently reported study).

\section{DISCUSSION}

The majority of morphological characters of the presently reported specimen are consistent with those of the holotype and paratypes of $P$. tessellata given by Carpenter (1987): dorsal fin with 10 spines and 15 soft rays; anal fin with 12 soft rays; pectoral fin with 20 rays; lateralline scales 73; circumpeduncular scales $13+15$; a single yellow longitudinal stripe on body lateral, about a single scale wide, from upper margin of eye to caudal peduncle, covering lateral line for most of its length (Table 1). The length of caudal peduncle length and length of 2nd dorsalfin spine of presently reported specimen differed $0.1 \%$ from the holotype and paratypes. These small differences are herein simply considered as intraspecific variations.

Among its congeners, $P$. tessellata is similar to P. chrysozona, $P$. digramma, and $P$. marri, sharing a longitudinal stripe covering lateral line with two distinct blotches on the tips of each caudal-fin lobes (Carpenter 1987) (Fig. 2). Pterocaesio chrysozona also has only one stripe on body side, but has another upper stripe on dorsal midline along base of dorsal fin (vs. absent in P. chrysozona). In addition, the mid-lateral stripe of Pterocaesio chrysozona is broader anteriorly, the width of two or three scales (vs. a stripe of a single width throughout), and directly below lateral line in anterior and above lateral line on caudal peduncle (vs. covering lateral line throughout).

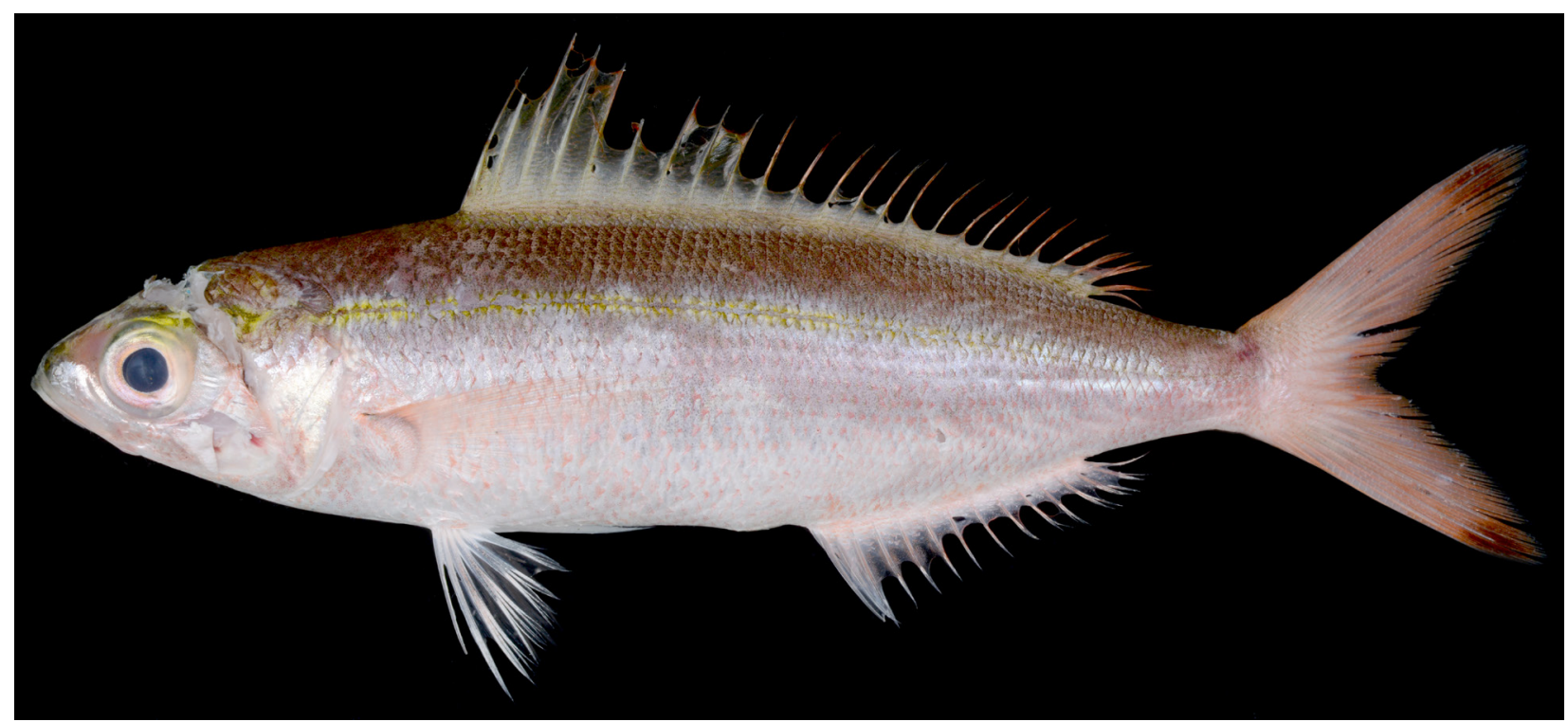

Fig. 1. Fresh specimen of Pterocaesio tessellata from south-western Taiwan; KAUM-I. 115115, 101.6 mm SL 
Table 1

Counts and measurements of specimen from south-western Taiwan and holotype and paratypes of Pterocaesio tessellata; data for type series extracted from Carpenter (1987)

\begin{tabular}{|c|c|c|c|}
\hline & $\begin{array}{c}\text { Non-type } \\
\text { KAUM-I. } 115115\end{array}$ & $\begin{array}{c}\text { Holotype } \\
\text { BPBM } 30821\end{array}$ & $\begin{array}{l}\text { Paratypes } \\
\quad n=5\end{array}$ \\
\hline Standard length (SL) [mm] & 101.6 & 104.0 & $89.3-175.0$ \\
\hline \multicolumn{4}{|l|}{ Counts } \\
\hline Dorsal-fin rays & $\mathrm{X}, 15$ & $\mathrm{X}, 15$ & $\mathrm{X}-\mathrm{XI}, 14-16$ \\
\hline Anal-fin rays & III, 12 & III, 12 & III, $12-13$ \\
\hline Pectoral-fin rays & 20 & 21 & $20-22$ \\
\hline Pelvic-fin rays & $\mathrm{I}, 5$ & $\mathrm{I}, 5$ & $\mathrm{I}, 5$ \\
\hline L-L scales & 73 & 73 & $69-77$ \\
\hline L-L scales anterior to vertical at anal-fin origin & 32 & 32 & $31-35$ \\
\hline L-L scales anterior to vertical at dorsal-fin origin & 9 & 9 & $9-10$ \\
\hline L-L scales anterior to vertical at pelvic-fin origin & 6 & 7 & $5-8$ \\
\hline Circumpeduncular scales & $13+15$ & $11+15$ & $11-14+15-17$ \\
\hline Scales above lateral line to origin of dorsal fin & 9 & 10 & $9-11$ \\
\hline Scales below lateral line to origin of anal fin & 15 & 17 & $16-18$ \\
\hline Scales on cheek & 4 & 5 & $4-5$ \\
\hline Pre-dorsal-fin scales & damaged & 23 & $22-29$ \\
\hline Gill rakers & $10+26$ & $9+26$ & $8-11+24-28$ \\
\hline \multicolumn{4}{|l|}{ Measurements [\% of SL] } \\
\hline Body depth & 24.9 & 25.0 & $24.9-30.2$ \\
\hline Body width & 16.2 & 15.8 & $15.1-17.3$ \\
\hline Head length & damaged & 29.2 & $29.2-30.5$ \\
\hline Snout length & 7.1 & 7.1 & $6.4-7.2$ \\
\hline Eye diameter & 8.0 & 7.9 & $6.6-8.3$ \\
\hline Bony interorbital width & 7.7 & 7.4 & $6.9-7.8$ \\
\hline Caudal peduncle depth & 8.1 & 8.1 & $8.1-8.4$ \\
\hline Caudal peduncle length & 14.1 & 16.3 & $14.2-17.0$ \\
\hline Predorsal-fin length & damaged & 37.2 & $35.9-38.3$ \\
\hline Preanal-fin length & 63.5 & 64.0 & $63.0-68.2$ \\
\hline Prepelvic-fin length & 34.8 & 36.9 & $34.9-37.0$ \\
\hline Dorsal-fin base length & 50.8 & 50.5 & $50.1-52.6$ \\
\hline Anal-fin base length & 23.2 & 23.5 & $21.2-22.9$ \\
\hline Pectoral-fin length & 25.5 & 26.7 & $26.4-29.5$ \\
\hline Pelvic-fin length & 17.5 & 16.3 & $16.0-17.7$ \\
\hline Pelvic-fin spine length & 12.3 & 11.9 & $11.5-12.5$ \\
\hline Length of 1 st dorsal-fin spine & 3.8 & 4.6 & $3.4-4.1$ \\
\hline Length of 2nd dorsal-fin spine & 13.1 & 11.9 & $10.8-13.0$ \\
\hline Length of 3 rd dorsal-fin spine & damaged & 14.9 & $13.3-16.0$ \\
\hline Length of 4 th dorsal-fin spine & 15.1 & 14.5 & $13.2-15.5$ \\
\hline Length of last dorsal-fin spine & 8.9 & 8.0 & $6.1-9.0$ \\
\hline Length of 1 st dorsal-fin soft ray & 8.5 & 8.1 & $6.6-9.3$ \\
\hline Length of 1st anal-fin spine & 2.9 & 2.7 & $2.2-3.4$ \\
\hline Length of 2 nd anal-fin spine & 10.4 & 10.6 & $9.8-10.8$ \\
\hline Length of 3 rd anal-fin spine & 10.7 & 10.5 & $9.7-11.2$ \\
\hline Length of 1st anal-fin soft ray & 10.2 & 9.6 & $7.9-10.5$ \\
\hline Longest caudal-fin ray length & 30.5 & 29.2 & $29.2-31.6$ \\
\hline
\end{tabular}

$\mathrm{L}-\mathrm{L}=$ lateral line. 
Pterocaesio tessellata has not been previously recorded from record of the species. Combined with Koeda and Ho (2018), two Taiwanese waters, and the northernmost record of the species species of genus Pterocaesio are newly reported from Taiwan, was from the Philippines (Carpenter 1987, Tatsukawa 2017). bringing the total number of Pterocaesio species known from The specimen collected from south-western Taiwan represents Taiwan to seven. An identification key to the species of genus the first record of $P$. tessellata from Taiwan and, the northernmost Pterocaesio in Taiwan is provided below (Table 2).
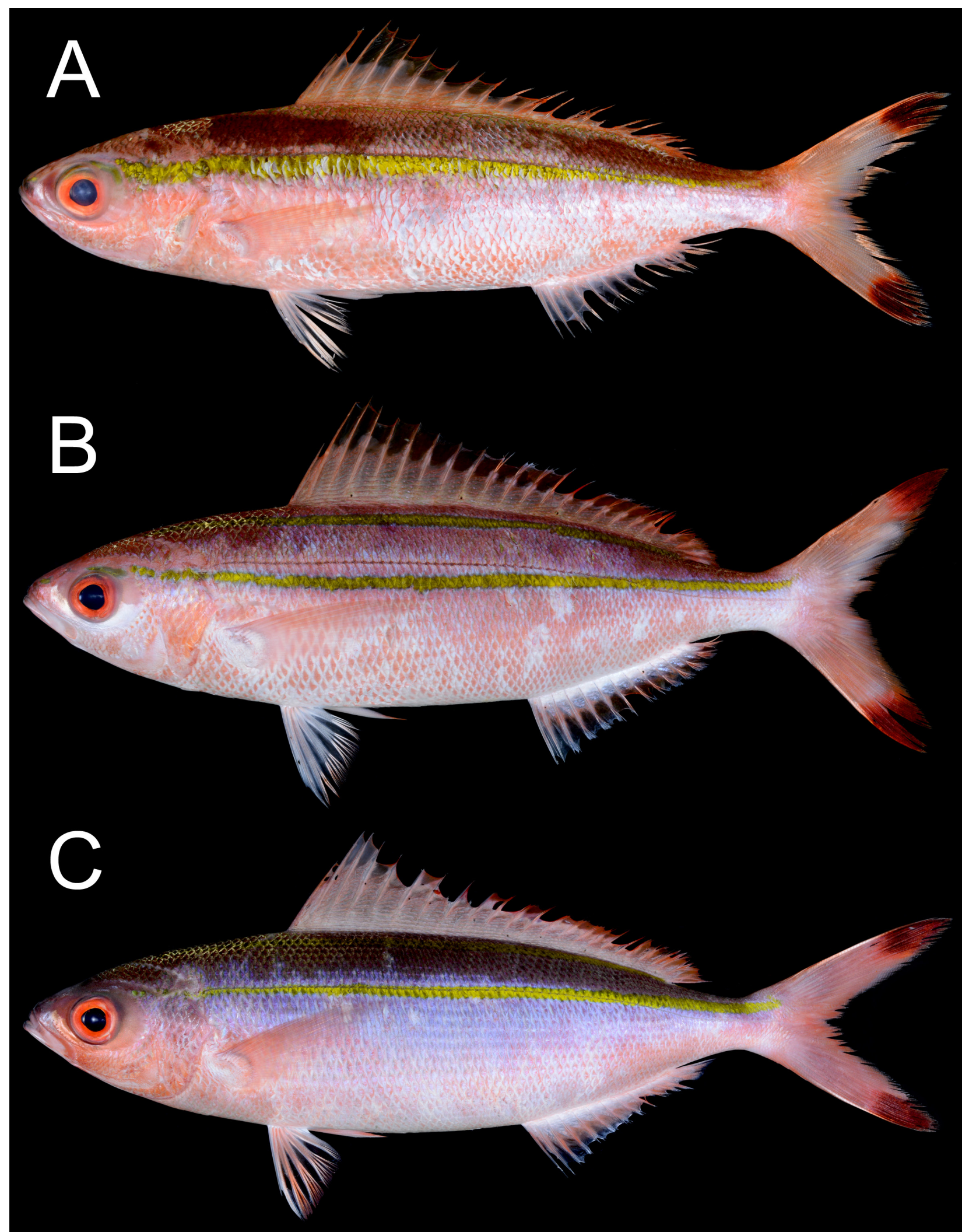

Fig 2 (A-C). Fresh specimens of genus Pterocaesio collected from south-western Taiwan; P. chrysozona, NMMB-P26621, 160.5 mm SL (A); P. digramma, NMMB-P26632, 187.3 mm SL (B); P. marri, NMMB-P26634, 179.4 mm SL (C) 


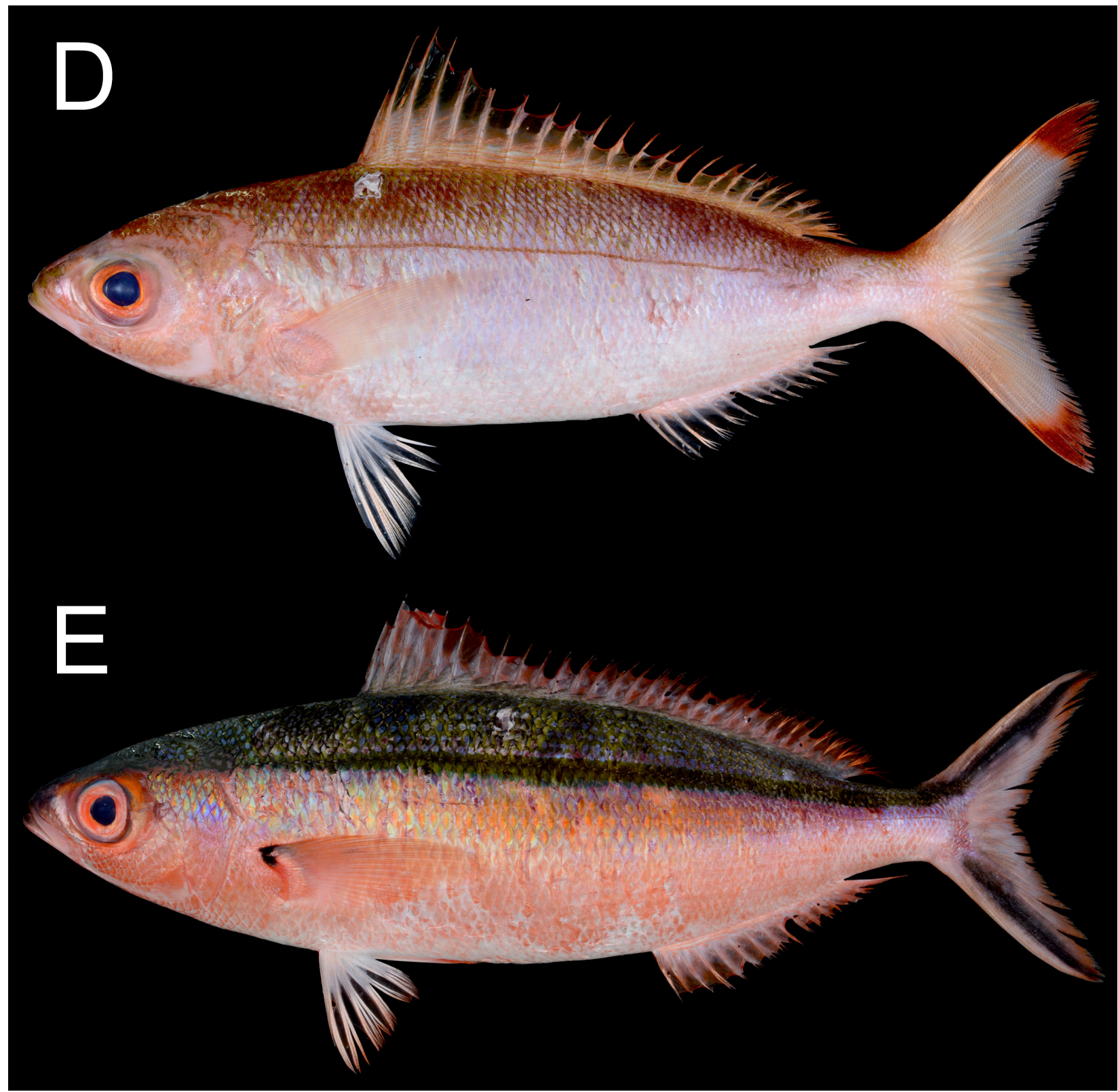

Fig 2 (D-E). Fresh specimens of genus Pterocaesio collected from south-western Taiwan; P. pisang, NMMB-P26622, 155.2 mm SL (D); P. tile, NMMB-P29737, 211.4 mm SL (reversed horizontally) (E)

Comparative materials. All specimens collected off Kenting, southern Taiwan. Pterocaesio chrysozona: NMMB-P26621, $160.5 \mathrm{~mm} \mathrm{SL} ; \quad P$. digramma, NMMB-P26632, 187.3 mm SL; P. marri, NMMB-P26634, $179.4 \mathrm{~mm}$ SL; P. pisang, NMMB-P26622, $155.2 \mathrm{~mm}$ SL; P. tile, NMMB-P29737, $211.4 \mathrm{~mm}$ SL. A key to the species of genus Pterocaesio in Taiwan is provided in Table 2.

\section{ACKNOWLEDGEMENTS}

We are especially grateful to $\mathrm{H}$. Wada and T. Uejo (KAUM), and J.-F. Huang (National Museum of Marine Biology \& Aquarium) for supporting the fish collection. We also thank H. Motomura and students of Kagoshima University for curatorial assistance. The presently reported study was supported in part by a JSPS Overseas Research Fellowships (29-304) to the first author.

\section{REFERENCES}

Adrim M., Chen I.-S., Chen Z.-P., Lim K.K.P., Tan H.H., Yusof Y., Jaffar Z. 2004. Marine fishes recorded from the Anambas and Natuna Islands, South China Sea. The Raffles Bulletin of Zoology 2004 (Suppl. 11): 117-130.

Allen G.R., Adrim A. 2003. Coral reef fishes of Indonesia. Zoological Studies 42 (1): 1-72.

Allen G.R., Erdmann M.V. 2012. Reef fishes of the East Indies. Vol. 1-3. Tropical Reef Research, Perth WA, Australia.

Carpenter K.E. 1987. Revision of the Indo-Pacific fish family Caesionidae (Lutjanoidea), with descriptions of five new species. Indo-Pacific Fishes No. 15: 1-56, pls. $1-7$.

Carpenter K.E. 2000. Caesionidae. P. 618. In: Randall J.E., Lim K.K.P. (eds.) A checklist of the fishes of the 
Key to the species of genus Pterocaesio in Taiwan

1a. Dorsal-fin rays XI-XII, 19-22; a blackish streak in each caudal-fin lobe

Pterocaesio tile (Fig. 2E)

1b. Dorsal-fin rays X-XI, 14-16; tip of each caudal-fin lobes with a blackish blotch

2a. No stripes on body side; a large distinct blotch present or absent on body side...

2b. One or two stripes on body lateral; no large distinct blotch on body side

3a. A large yellow blotch above pectoral fin.

Pterocaesio randalli (not reliable record from Taiwan)

3b. Body without distinct coloration on body side Pterocaesio pisang (Fig. 2D)

4a. One yellow longitudinal stripe on body side. 6

4b. Two yellow longitudinal stripes on body side 5

5a. No stripe on dorsal midline; stripe on body thin (width of one scale), covering lateral line for most its length Pterocaesio tessellata (Fig. 1)

5b. One stripe on dorsal midline on nape and along base of dorsal fin; stripe on body side broader (width of two to three scales) anteriorly, directly below lateral line for most of its length ......... Pterocaesio chrysozona (Fig. 2A)

6a. Lower longitudinal stripe distinctly below lateral line for most its length .......... Pterocaesio digramma (Fig. 2B)

6b. Lower longitudinal stripe covering lateral lie for most its length............................Pterocaesio marri (Fig. 2C)

South China Sea. The Raffles Bulletin of Zoology 2000 (Suppl. 8): 569-667.

Carpenter K.E. 2001. Caesionidae. Pp. 2919-2941. In: Carpenter K.E., Niem V.H. (eds.), FAO Species Identification Guide for Fishery Purposes. The Living Marine Resources of the Western Central Pacific, Vol. 5. Bony fishes part 3 (Menidae to Pomacentridae), Estuarine Crocodiles, Sea Turtles, Sea Snakes and Marine Mammals. FAO, Rome.

Fricke R., Allen G.R., Andréfouët S., Chen W.-J., Hamel M.A., Laboute P., Mana R., Hui T.H., Uyeno D. 2014. Checklist of the marine and estuarine fishes of Madang District, Papua New Guinea, western Pacific Ocean, with 820 new records. Zootaxa 3832: 1-247. DOI: $10.11646 /$ zootaxa.3832.1.1

Fricke R., Eschmeyer W.N., van der Laan R. (eds.) 2018. Catalog of fishes: Genera, species, references. California Academy of Sciences, San Francisco, USA. [Accessed on 25 September 2018.] http://researcharchive.calacademy.org/research/ ichthyology/catalog/fishcatmain.asp

Iwatsuki Y. 2009. Pterocaesio tessellata. P. 147. In: Kimura S., Satapoomin U., Matsuura K. (eds.) Fishes of Andaman Sea, west coast of southern Thailand. National Museum of Nature and Science, Tokyo, Japan.
Koeda K., Ho H.-C. 2018. A new specimen-based and northern most records of the banana fusilier Pterocaesio pisang (Perciformes: Caesionidae) in Taiwan. Platax 15: 37-43.

Myers R.F. 1999. Micronesian reef fishes. 3rd edn. Coral Graphics, Guam.

Peristiwady T., Suharti S.R., Kimura S. 2003. Pterocaesio tessellata. P. 92. In: Kimura S., Matsuura K. (eds.) Fishes of Bitung, northern tip of Sulawesi, Indonesia. Ocean Research Institute, Tokyo.

Shen S.-C., Wu K.-Y. 2011. [Fishes of Taiwan.] National Museum of Marine Biology and Aquarium, Checheng, Taiwan. [In Chinese.]

Tatsukawa H. 2017. Pterocaesio tessellata. P. 139. In: Motomura H., Alama U.B., Muto N., Babaran R.P., Ishikawa S. (eds.) Commercial and bycatch market fishes of Panay Island, Republic of the Philippines. The Kagoshima University Museum, Kagoshima, University of the Philippines Visayas, Iloilo, and Research Institute for Humanity and Nature, Kyoto, Japan.

Received: 9 July 2018

Accepted: 2 October 2018

Published electronically: 15 March 2019 